Correction

\title{
Al-Mousawi, S.M., et al. Azolylacetones as Precursors to Indoles and Naphthofurans Facilitated by Microwave Irradiation with Simultaneous Cooling. Molecules 2009, 14, 2976-2984
}

\section{Saleh Mohammed Al-Mousawi * and Morsy Ahmed El-Apasery}

Department of Chemistry, Faculty of Science; University of Kuwait, Safat, 13060, P.O. Box 12613, Kuwait

* Author to whom correspondence should be addressed; E-Mail: saleh.almousawi@yahoo.com; Tel.: +965-24985547; Fax: +965-24816482.

Received: 28 December 2009 / Published: 28 December 2009

We realized that the title was incorrectly listed in our paper published in Molecules recently [1]. The correct title is indicated below:

\section{Azolylacetones as Precursors to Indoles and Naphthofurans Facilitated by Microwave Irradiation with Simultaneous Cooling}

\section{Reference}

1. Al-Mousawi, S.M.; El-Apasery, M.A. Azolyacetones as precursors to indoles and naphthofurans facilitated by microwave irradiation with simultaneous cooling. Molecules 2009, 14, 2976-2984.

(C) 2010 by the authors; licensee Molecular Diversity Preservation International, Basel, Switzerland. This article is an open-access article distributed under the terms and conditions of the Creative Commons Attribution license (http://creativecommons.org/licenses/by/3.0/). 